\title{
Hypothalamic Lesions That Induce Female Precocious Puberty Activate Glial Expression of the Epidermal Growth Factor Receptor Gene: Differential Regulation of Alternatively Spliced Transcripts
}

\author{
Marie-Pierre Junier, ${ }^{1, a}$ Diane F. Hill, ${ }^{1}$ Maria E. Costa,' Stephen Felder, ${ }^{2, b}$ and Sergio R. Ojeda1 \\ ${ }^{1}$ Division of Neuroscience, Oregon Regional Primate Research Center, Beaverton, Oregon 97006 and ${ }^{2}$ Rhone-Poulenc \\ Rorer Central Research, Horsham, Pennsylvania 19044
}

Injury of the nervous system triggers a complex series of repair mechanisms that include production of neurotrophic and mitogenic factors by cells neighboring the injured area. While trauma of most parts of the brain results in loss of function, lesions of certain regions of the female hypothalamus enhance the secretory activity of a group of specialized neurons that produce luteinizing hormone-releasing hormone (LHRH), the neuropeptide that controls sexual development. The increased output of LHRH causes sexual precocity by prematurely activating the neuroendocrine reproductive axis. Recent studies have implicated transforming growth factor $\alpha$ (TGF $\alpha$ ) produced by reactive astrocytes in the process by which lesions hasten sexual maturation, and have suggested that the stimulatory actions of TGF $\alpha$ on LHRH neurons require the intermediacy of epidermal growth factor receptors (EGFRs). In the present study, we examined the changes in EGFR gene expression following lesions of the preoptic-anterior hypothalamic area (POA-AHA) of immature female rats, identified the cell types where EGFR synthesis increases, and assessed the biochemical activity of the newly formed EGFR protein. RNase protection assays demonstrated that the lesion significantly increased the levels of a predominant mRNA transcript encoding the full-length, membrane-spanning EGFR, but did not affect those of a much less abundant, alternatively spliced mRNA that encodes a truncated, presumably secreted form of EGFR. Following lesions, antibody-induced EGFR kinase activity increased twofold. Antibodies directed against a peptide sequence contained within the carboxy terminus of EGFR showed intense EGFR immunoreactivity in cells surrounding the lesion site; double immunohistochemistry identified these cells as astrocytes since EGFR immunoreactivity was colocalized with that of glial fibrillary acidic protein, an astrocytic marker. That these changes result from an increase in EGFR gene expression was indicated by the elevated levels of EGFR mRNA detected by in situ hybridization in cells of

Received May 1, 1992; revised July 30, 1992; accepted Aug. 5, 1992.

This work was supported in part by NIH Grants HD-25123, RR00163, and HD-18185. This is Publication 1855 of the Oregon Regional Primate Research Center.

Correspondence should be addressed to Dr. Sergio R. Ojeda, Division of Neuroscience, Oregon Regional Primate Research Center, 505 N.W. 185th Avenue, Beaverton, OR 97006.

aPresent address: C.J.F. INSERM 9102, C.H.U. Henri Mondor, Créteil, France.

pPresent address: Department of Pharmacology, Selectide Corporation, 10900 North Stallard Place, Suite 122, Tucson, AZ 98737.

Copyright (c) 1993 Society for Neuroscience $0270-6474 / 93 / 130703-11 \$ 05.00 / 0$ the same area. Although POA-AHA lesions did not result in appearance of EGFR in LHRH neurons themselves, EGFRpositive cells and processes were seen in close proximity to LHRH neurons and their nerve terminals, particularly in the area surrounding the lesion. Since TGF $\alpha$ gene expression is also increased in reactive astrocytes of POA-AHA lesions and blockade of EGFR prevented the advancing effect of the lesion on puberty (Junier et al., 1991b), the present results support the concept that, in lesioned animals, TGF $\alpha$ stimulates LHRH secretion indirectly via a paracrine mechanism that involves its interaction with EGFRs located on astroglial cells.

IKey words: hypothalamic injury, epidermal growth factor receptor mRNA transcripts, astrocytes, peptidergic neurons, sexual precocity, glial-neuronal interaction]

It is well established that lesions of the hypothalamus cause female sexual precocity in both experimental animals and humans (Donovan and van der Werff Ten Bosch, 1956; Balagura et al., 1979). While in rodents the most effective area appears to be a region encompassing the posterior portion of the preoptic area and the anterior hypothalamic area, more caudal lesions are also effective (Critchlow and Bar-Sela, 1967), suggesting that the nature of the tissue reaction to injury and its proximity to luteinizing hormone-releasing hormone (LHRH) neurons, rather than the injured area per se, are important for triggering the process. LHRH neurons are highly specialized neuroendocrine cells whose main neurosecretory product is LHRH, a decapeptide that regulates pituitary secretion of gonadotropins and hence is essential for sexual development and maintenance of adult reproductive function. In rats, most LHRH neurons are located in the preoptic region rostral to the hypothalamus; in primates they mostly reside within the medial basal hypothalamus (Silverman, 1988). It is thus not surprising that in nonhuman primates, lesions of the posterior hypothalamus are more effective in eliciting sexual precocity (Terasawa et al., 1984), although again, injury of more rostral areas that do not compromise the LHRH neuronal network can also hasten sexual development (Norman and Spies, 1984).

Elucidation of the molecular mechanisms underlying the ability of hypothalamic lesions to induce sexual precocity is important, not only because of its implications for the understanding of precocious puberty of cerebral origin in humans, but also because they represent a unique example of specialized neuronal activation leading to enhancement of a physiological function in response to injury. Such a response is in marked contrast with the loss of function associated with most injuries of the 
CNS. While some cases of sexual precocity can be readily associated with the presence of tumors or traumatic hypothalamic damage (Marks and Elders, 1979), the vast majority of female cases are suspected to be of central origin but are diagnosed as idiopathic (Kaplan and Grumbach, 1990). In recent years, the availability of computer axial tomography has allowed more of these cases to be attributed to discrete hypothalamic lesions (Cacciari et al., 1983; Kaplan and Grumbach, 1990). Whether the activation of LHRH neurons is caused by a discrete derangement of cellular function in the vicinity of LHRH neurons or by gross alteration of hypothalamic homeostasis, such as that caused by invading or compressing tumors, the participation of growth factors in the etiology of the process needs careful consideration.

Brain injury results in the appearance of various mitogenic and neurotrophic activities in the area surrounding the lesion (Nieto-Sampedro and Cotman, 1985). Among the known trophic factors whose expression is enhanced by brain lesions are acidic and basic fibroblast growth factors (aFGF and bFGF, respectively) (Finklestein et al., 1988; Nieto-Sampedro et al., 1988a; Logan et al., 1991); platelet-derived growth factor (Takamiya et al., 1986); NGF (Whittemore et al., 1987; Bakhit et al., 1991); insulin-like growth factor II (Logan et al., 1991) and transforming growth factor B. An increase in epidermal growth factor receptor (EGFR) immunoreactivity following lesions has also been reported (Nieto-Sampedro et al., 1988b).

In examining the ability of some of these trophic factors to affect the release of hypothalamic LHRH, we found that EGF and transforming growth factor $\alpha$ (TGF $\alpha$ ), but not bFGF or transforming growth factors $\beta_{1}$ and $\beta_{2}$, were able to enhance I.HRH secretion from median eminence nerve terminals in vitro, indicating that this effect does not require the presence of LHRH neuronal perikarya (Ojeda et al., 1990). We further demonstrated that the effect of TGF $\alpha$ was mediated by a prostaglandin, presumably prostaglandin $\mathrm{E}_{2}\left(\mathrm{PGE}_{2}\right)$, and involved activation of the EGFR tyrosine kinase. More recently, we demonstrated that hypothalamic lesions that elicit sexual precocity result in activation of the TGF $\alpha$ gene in reactive astrocytes surrounding the lesion site (Junier et al., 199lb). This activation preceded the initiation of precocious puberty and was accompanied by changes in LHRH secretion, in the face of seemingly unaltered LHRH mRNA levels and processing of the LHRH prohormone (Junier et al., 1992). The ability of tyrphostin RG-50864, a recently developed compound that selectively blocks EGFR tyrosine kinase activity (Yaish ct al,, 1988), to prevent the advancing effect of the lesion on puberty suggested the involvement of EGFR-like molecules in the process by which hypothalamic lesions activate LHRH neurons. Because most EGFRs have been shown to be present in astroglial cells (Leutz and Schachner, 1981; Simpson et al., 1982; Wang et al., 1989), we postulated that the effects of TGF $\alpha$ on LHRH neurons were not direct, but involved a glial-neuronal interaction instead. According to this concept, TGF $\alpha$ would interact with EGFRs located on reactive astrocytes to induce prostaglandin release (Ojeda et al., 1990; Junier et al., 1991b). One such prostaglandin, presumably $\mathrm{PGE}_{2}$, would then act on LHRH nerve terminals to elicit LHRH secretion.

We now provide evidence that lesions of the preoptic-anterior hypothalamic area (POA-AHA) of immature female rats result in enhanced expression of the EGFR gene in reactive astrocytes surrounding the lesion site, and that even though LHRH neurons appear to be in close contact with EGFR-positive cells, they themselves are not endowed with EGFRs.
A partial report of these findings has appeared previously (Junier et al., 1991a).

\section{Materials and Methods}

Animals. Immature female rats of the Sprague-Dawley strain purchased from Bantin and Kingman (Fremont, CA) were housed under controlled conditions of temperature $\left(23-25^{\circ} \mathrm{C}\right)$ and photoperiod $(10 \mathrm{hr}$ darkness/ $14 \mathrm{hr}$ light, lights on from 0500 to $1900 \mathrm{hr}$ ) and had free access to tap water and pelleted food (Purina Laboratory Chow, Ralston-Purina, St. Louis, MO).

At $22 \mathrm{~d}$ of age, the animals were anesthetized with ether and subjected to bilateral radio frequency lesions (Advis and Ramirez, 1977; Junier et al., 1991b), directed to a region comprising the posterior portion of the preoptic area and the rostral part of the anterior hypothalamic area (henceforth referred to as POA-AHA). The stereotaxic coordinates used $(0.8 \mathrm{~mm}$ anterior to bregma, $8 \mathrm{~mm}$ ventral to the surface of the skull, and $0.4 \mathrm{~mm}$ lateral from the midline) were based on the atlas of DeGroot (1959). Lesions were made utilizing a Grass lesion maker that delivered a current of $5 \mathrm{~mA}$ for $25 \mathrm{sec}$.

Since these lesions result in precocious puberty within a week (Advis and Ramirez, 1977; Junier et al., 1991b) and maximal levels of TGF $\alpha$ mRNA within 4-6 d (Junier et al., 1991b), all animals were killed between 5 and $7 \mathrm{~d}$ after the lesion. Age-matched control rats were killed either at $28 \mathrm{~d}$ of age, a time at which they were immature, or at the time of normal puberty (34-38 d of age). At death, the animals were classified in different stages of sexual development, using previously established criteria (Advis et al., 1979). Animals with small uteri $(<60$ $\mathrm{mg}$ ) and no signs of intrauterine accumulation of fluid werc considered juveniles and classified as belonging to the anestrus (A) phase of puberty. Animals showing uterine fluid were considered to be in the early proestrus (EP) or late proestrus (LP) phase of puberty. Accumulation of uterine fluid results from the peripubertal rise in estrogen levels initiated in $E P$ and reaches maximal values in $L P$, a time at which it triggers the first preovulatory surge of gonadotropins (Ojeda and Urbanski, 1988). In normal animals, the two stages can be differentiated from one another by the uterine weight, which is always greater than $200 \mathrm{mg}$ in LP animals. Since this criterion cannot be used in animals undergoing precocious puberty because their uterine weights are lower, lesioned animals exhibiting accumulation of intrauterine fluid were considered to be "stimulated," without attempting to classify them in either the EP or LP phases of puberty. The rat vagina usually becomes patent on the day of first ovulation that follows the preovulatory surge of gonadotropins. At this time, vaginal cytology shows a predominance of cornified cells due to estrogen stimulation. Animals exhibiting these features were classified as in the estrus (E) phase of puberty. Fresh corpora lutea in the ovaries verified the occurrence of the first ovulation.

Tissue dissection. POA-AHA tissue was collected for RNA measurement and receptor autophosphorylation experiments. Dissection boundaries were, caudally, halfway between the posterior border of the optic chiasm and the anterior border of the mammillary bodies; laterally, the hypothalamic sulci; and rostrally, the anterior border of the optic chiasm; depth, $2 \mathrm{~mm}$.

RNA isolation. Total RNA was isolated by the acid phenol method of Chomczynski and Sacchi (1987), as previously described (Lara et al., 1990; Ojeda et al., 1990).

Nucleic acid probes. EGFR mRNA was detected with an antisense RNA probe transcribed from a sequence contained within ER-ts, a 2.3 kilobase rat EGFR cDNA (Petch et al., 1990). The DNA template used for transcription was obtained by subcloning a blunt-ended Sau3A1 fragment [nucleotides (nt) 1720-2298 of EGFR mRNA] into the Sma1 site of the riboprobe vector pBluescript SK II. This fragment spans the site of divergency (located at nt 2076) between the mRNAs encoding the full-length EGFR and the truncated EGFR form. Linearization of the template at nt 1915 with AvalI yields a 383 base pair (bp) DNA template of which $160 \mathrm{bp}$ corresponds to the sequence common to the external domain of the full-length EGFR mRNA and its truncated form, and $223 \mathrm{bp}$, to the unique $3^{\prime}$ end of the truncated EGFR mRNA.

In vitro transcription of this fragment was performed as reported previously (Lara et al., 1990), using T7 polymerase and a radiolabeled nucleotide. The nucleotides used were ${ }^{32} \mathrm{P}-\mathrm{CTP}$ for RNA blot hybridizations and RNase protection assays and ${ }^{35} \mathrm{~S}-\mathrm{UTP}$ for hybridization histochemistry.

Solution hybridization/RNase protection assay. An RNase protection assay was used to determine if POA-AHA lesions increase the levels of the mRNA transcript that encodes the full-length EGFR and/or affect 
the splicing of the EGFR primary mRNA transcript to change the levels of the EGFR mRNA species encoding the truncated EGFR form.

The assay used was based on that reported by Gilman (1989), with some modifications (Junier et al., 1991b; Hill et al., 1992). In brief, total RNA samples $(15 \mu \mathrm{g})$ were dried by vacuum centrifugation, reconstituted in $30 \mu \mathrm{l}$ of assay buffer ( $80 \%$ formamide in $40 \mathrm{~mm}$ PIPES, pH $6.4,0.4 \mathrm{M} \mathrm{NaCl}, 1 \mathrm{~mm}$ EDTA) containing $500,000 \mathrm{cpm}$ of ${ }^{32} \mathrm{P}$ (piperazine-N, $\mathrm{N}^{\prime}$-bis[2-ethanesulfonic acid])-labeled CTP, and hybridized overnight at $45^{\circ} \mathrm{C}$. All tubes also contained $5000 \mathrm{cpm}$ of a cyclophilin cRNA probe (Junier et al., 1991b) added to the reaction to correct for procedural losses. Cyclophilin mRNA is expressed constitutively in brain tissue (Danielsson et al., 1988). Prior to hybridization, the radiolabeled probe was isolated by polyacrylamide gel electrophoresis (PAGE), elution, and ethanol precipitation. Following hybridization, the unprotected RNA species were digested with ribonucleases $A$ and $T_{1}$ and the protected radiolabeled species were isolated by electrophoresis in a $5 \%$ polyacrylamide, $7 \mathrm{M}$ urea gel. To visualize the protected fragments, the gels were dried and exposed to Kodak XAR-5 film for different times at $-85^{\circ} \mathrm{C}$. The hybridization signals were scanned with an LKB Ultrascan XL Laser Densitometer and normalized using the levels of cyclophilin mRNA detected in each sample. The values obtained were compared to a standard curve constructed with different concentrations of in vitro transcribed EGFR sense RNA. Quantitation of the full-length and truncated EGFR mRNA forms was performed on autoradiograms containing both the standard curve and samples and that resulted from either $20 \mathrm{hr}$ (full-length EGFR mRNA) or $7 \mathrm{~d}$ (truncated form) of film exposure to the gel. Additional details of the procedure were previously reported (Junier et al., 1991b; Hill et al., 1992). Differences between groups were analyzed by one-way analysis of variance followed by Student's $t$ test.

Hybridization histochemistry. Prior publications described the procedure employed in detail (Dissen et al., 1991; Junier et al., 1991b). In the present study, brains were fixed by transcardiac perfusion of the animals with $4 \%$ paraformaldehyde in $0.1 \mathrm{~m}$ borate buffer, $\mathrm{pH} 9.5$. Thereafter, they were postfixed overnight at $4^{\circ} \mathrm{C}$ in the same fixative containing $10 \%$ sucrose, blocked, and frozen at $-85^{\circ} \mathrm{C}$ before sectioning. Following treatment with proteinase $\mathrm{K}$ and acetic anhydride (Simmons et al., 1989), the sections ( $20 \mu \mathrm{m}$, cut with a sliding microtome) were overlaid with $70 \mu \mathrm{l}$ of hybridization buffer $(50 \%$ formamide, $0.2 \mathrm{M} \mathrm{NaCl}$, $10 \mathrm{~mm}$ Tris, pH 8.0,10 mM EDTA, $2 \times$ Denhardt's solution) containing $5 \times 10^{6} \mathrm{cpm} / \mathrm{ml}$ of labeled EGFR probe, and incubated for $18 \mathrm{hr}$ at $55^{\circ} \mathrm{C}$. The posthybridization washes included incubation of the sections with ribonuclease $A\left(30 \mathrm{~min}\right.$ at $\left.37^{\circ} \mathrm{C}, 20 \mu \mathrm{g} / \mathrm{ml}\right)$ and a last wash at $65^{\circ} \mathrm{C}$ for $30 \mathrm{~min}$ (Dissen et al., 1991). After dehydration in graded alcohols, the sections were dipped in Kodak NTB-2 emulsion, stored at $4^{\circ} \mathrm{C}$ for 3 weeks, developed, counterstained with thionin, and examined under both dark- and bright-field illumination. Control sections were incubated with an EGFR sense RNA probe transcribed from the same DNA template used to synthesize the antisense probe, but linearized with HindIII and transcribed with T3 polymerase.

Immunohistochemistry. Immunoreactive EGFRs were visualized in $75 \mu \mathrm{m}$ vibratome sections obtained after fixation of the brain via transcardiac perfusion of Zamboni's fixative. The immunohistochemical procedure used was an ABC peroxidase technique described by Nilaver and Kozlowski (1989) with minor modifications (Dissen et al., 1991; Junier et al., 1991b). The antiserum used (RK-2, at 1:1000 dilution) is directed against the peptide sequence 984-996 contained within the C-terminus of the human EGFR (Kris et al., 1985). The antibody has been used to immunoprecipitate the human EGFR (Kris et al., 1985) and to detect immunoreactive EGFRs in rat tissues (Suarez-Quian et al., 1989). In the present study, controls included either substitution of the primary antibody with preimmune serum or removal of the EGFR antibodies from the primary antiserum via binding to semipurified human EGFR. The latter procedure was carried out as follows: solubilized membranes of A-431 cells were incubated with wheat germ agglutininSepharose for $2 \mathrm{hr}$ at $4^{\circ} \mathrm{C}$. Following elution of bound glycoprotein with $0.5 \mathrm{M}$ acetylglucosamine, the semipurified EGFR was incubated with an excess of biotinylated EGF ( $2 \mu \mathrm{g}$; Boehringer Mannheim, Indianapolis, IN) for $1 \mathrm{hr}$ at $4^{\circ} \mathrm{C}$ in a $160 \mu \mathrm{l}$ volume. Two microliters of RK-2 antiserum were added, and the incubation was continued for another hour. This was followed by addition of $50 \mu$ l of avidin-agarose (Sigma Chemical Co., St. Louis, MO) and incubation of the suspension for 45 min at $4^{\circ} \mathrm{C}$, with end-over-end tipping. The tube was then microfuged to pellet the avidin-agarose-biotinylated EGF-EGFR-RK-2 complex, and the supernatant was incubated with another $50 \mu \mathrm{l}$ of avidin-agarose. After centrifugation, the supernatant was diluted with the buffer for immunohistochemistry $(0.05 \mathrm{M}$ Tris, $\mathrm{pH} 7.6$, containing $0.9 \% \mathrm{NaCl}$ $0.02 \% \mathrm{BSA}$, and $0.1 \%$ Triton $\mathrm{X}-100$ ) to a final dilution of $1: 1000$.

LHRH and EGFR or glial fibrillary acidic protein (GFAP) and EGFR immunoreactivities were simultaneously detected in $75 \mu \mathrm{m}$ vibratome sections utilizing the technique of Lakos and Basbaum (1986), as reported elsewhere (Junier et al., 1991b). Diaminobenzidine was employed as the chromogen to develop the LHRH and GFAP antibody reactions to a brown color, and benzidine dihydrochloride to develop the EGFR-RK 2 antibody reaction to a blue color. Identification of LHRH neurons was accomplished with monoclonal antibody $\mathrm{HU} 4 \mathrm{H}$ (Urbanski, 1991), at a 1:2000 dilution. This antibody has conformational immunospecificity and requires the entire decapeptide molecule for recognition. Astrocytes were identified with the GFAP antiserum R77 (a generous gift from Dr. L. Eng, Stanford University, Palo Alto, $\mathrm{CA})$ at 1:2000 dilution.

EGFR immunoprecipitation and autophosphorylation. Each hypothalamus, dissected as described above, was frozen in its own tube on dry ice and stored at $-85^{\circ} \mathrm{C}$ until the day of homogenization. All the following steps were performed on ice or at $4^{\circ} \mathrm{C}$ unless otherwise noted. Individual hypothalami were homogenized in $300 \mu \mathrm{l}$ of TG buffer (phosphate-buffered saline containing $1 \%$ Triton X-100, $10 \%$ glycerol, and 1 $\mu \mathrm{g} / \mathrm{ml}$ aprotinin) in a glass-glass homogenizer. After transfer of the homogenate to a microcentrifuge tube, the homogenizing tube and pestle were rinsed with an additional $300 \mu \mathrm{l}$ of TG buffer. Homogenates were kept on ice for an additional $1 \mathrm{hr}$ to ensure optimal solubilization.

After microcentrifugation for $5 \mathrm{~min}$, the sample supernatants were split into two clean tubes. A $50 \mu 1$ aliquot was removed for protein analysis using the Bio-Rad method with bovine serum albumin standards. The supernatant duplicates were frozen and kept at $-85^{\circ} \mathrm{C}$ until the day of assay.

Kinase assays were performed essentially as described previously (Decker, 1984). Samples containing equal amounts of protein (200-300 $\mu \mathrm{g}$ ) were adjusted to $0.5 \mathrm{ml}$ with TG buffer. Immunoprecipitation was initiated by adding $4 \mu \mathrm{l}$ of EGFR antiserum (\#1383, a generous gift from Dr. Sheldon Earp, University of North Carolina at Chapel Hill) or normal rabbit serum and tubes were tipped for $1.5 \mathrm{hr}$. Protein ASepharose ( $30 \mu \mathrm{l}$ of a 1:1 slurry in distilled water) was added to immunoprecipitate the EGFR-antibody complexes, and the tubes were tipped for an additional $1.5 \mathrm{hr}$. Immunoprecipitates were pelleted in the microcentrifuge and washed two times with $750 \mu \mathrm{l}$ of TG buffer. Following the addition of $30 \mu \mathrm{l}$ of $10 \mathrm{~mm}$ HEPES, $1 \mathrm{mM} \mathrm{MnCl}_{2}(\mathrm{pH}$ 7.4), tubes were removed from ice and the kinase reaction was initiated by the addition of $1 \mu \mathrm{l}$ of ${ }^{32} \mathrm{P}$-ATP $(6.5 \mu \mathrm{M}$; specific activity, $10 \mathrm{Ci} /$ mmol; DuPont-New England Nuclear, Boston, MA). After vortexing, the reaction was permitted to proceed for $7 \mathrm{~min}$ at room temperature and stopped by the addition of $15 \mu \mathrm{l}$ of $3 \times$ concentrated sample buffer $(1 \times=0.0625$ м Tris, $\mathrm{pH} 6.8,3 \%$ sodium dodecyl sulfate, $5 \%$ glycerol, $5 \% \beta$-mercaptoethanol, and $0.001 \%$ bromophenol blue). Samples were boiled for $10 \mathrm{~min}$ and cleared by centrifugation prior to SDS-PAGE on a $7 \%$ gel. Gels were dried and exposed to Kodak XAR-5 film at $-85^{\circ} \mathrm{C}$ with DuPont Cronex intensifying screens. Resulting autoradiograms were scanned with an LKB Ultrascan XL laser densitometer.

\section{Results}

Detection of EGFR $m R N A$ and its alternatively spliced shorter transcript by RNase protection assay

Figure $1 A$ shows a standard curve constructed by hybridizing different amounts of EGFR sense RNA to the EGFR cRNA probe. The cRNA is $458 \mathrm{nt}$ in length, of which $75 \mathrm{nt}$ correspond to vector sequences. The sense RNA transcript protects $408 \mathrm{nt}$, of which $25 \mathrm{nt}$ arc vector scquences. As shown in Figure $1 A$, the assay is able to detect down to $31 \mathrm{fg}$ of sense EGFR mRNA. Figure $1 C$ depicts the regression line derived from the hybridization signals shown in the upper panel. After $20 \mathrm{hr}$ of exposure, hypothalamic RNA is seen to protect a $160 \mathrm{nt}$ band (Fig. $1 B$, left lane) that corresponds to a sequence common to the fulllength EGFR mRNA and its truncated form, and that encodes a portion of the extracellular domain of EGFR close to the transmembrane domain (nt 1915-2076 in EGFR mRNA). Upon a longer exposure ( $7 \mathrm{~d}$ ), a $383 \mathrm{nt}$ species became detectable (Fig. $1 B$, right lane). This species has the length expected for a protected fragment composed of $160 \mathrm{nt}$ common to the extracellular 
A

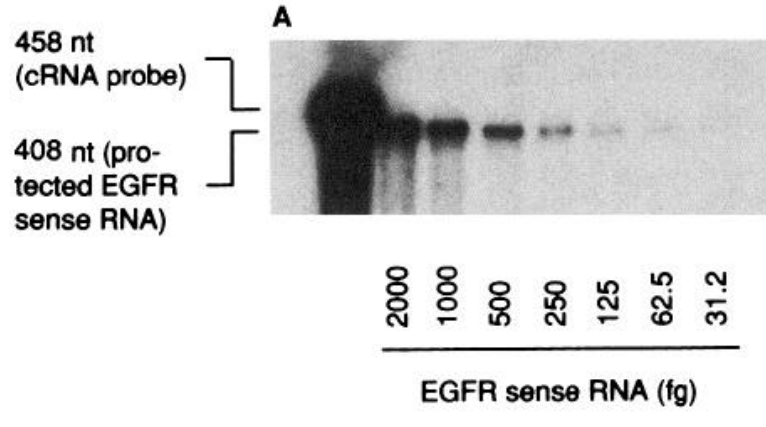

B

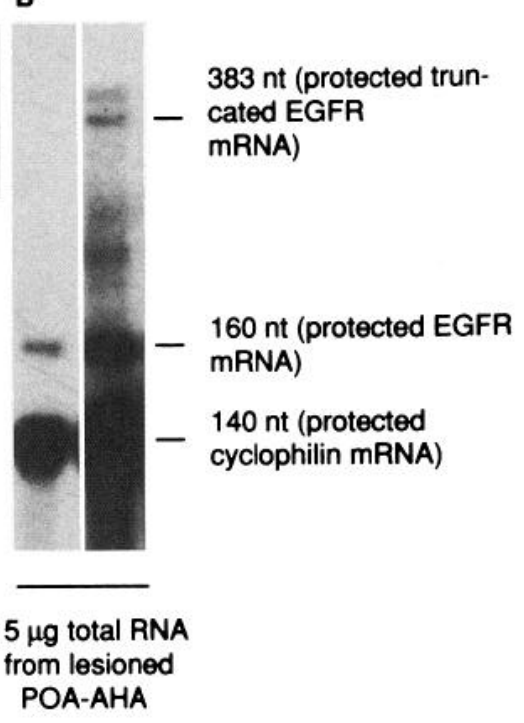

Figure 1. Detection of alternatively spliced EGFR mRNA transcripts by RNase protection assay in the POAAHA of rats bearing POA-AHA lesions. The tissues were collected $6 \mathrm{~d}$ after lesion. The autoradiogram depicted in $A$ shows a standard curve used to quantitate EGFR mRNA in the hypothalamus of lesioned and control animals. The curve was constructed by hybridizing different concentrations of in vitro transcribed EGFR sense mRNA with a ${ }^{32} \mathrm{P}$-labeled EGFR cRNA probe. $B$ shows a predominant $160 \mathrm{nt}$ mRNA form (left lane) that corresponds to the extracellular domain encoding region of EGFR mRNA and a $383 \mathrm{nt}$ protected species (right lane) that corresponds to the truncated EGFR mRNA form detected after $7 \mathrm{~d}$ of exposure of the gel to $x$-ray film. The upper band ( $458 \mathrm{bp}$ in length; right lane) probably corresponds to a small amount of undigested labeled probe. The strong $140 \mathrm{nt}$ band EGFR mRNA is cyclophilin mRNA used to normalize the mRNA values obtained. $C$ depicts the regression line obtained by plotting the indicated amounts of EGFR sense mRNA against their respective hybridization signals. below the $160 \mathrm{nt}$ fragment protected by

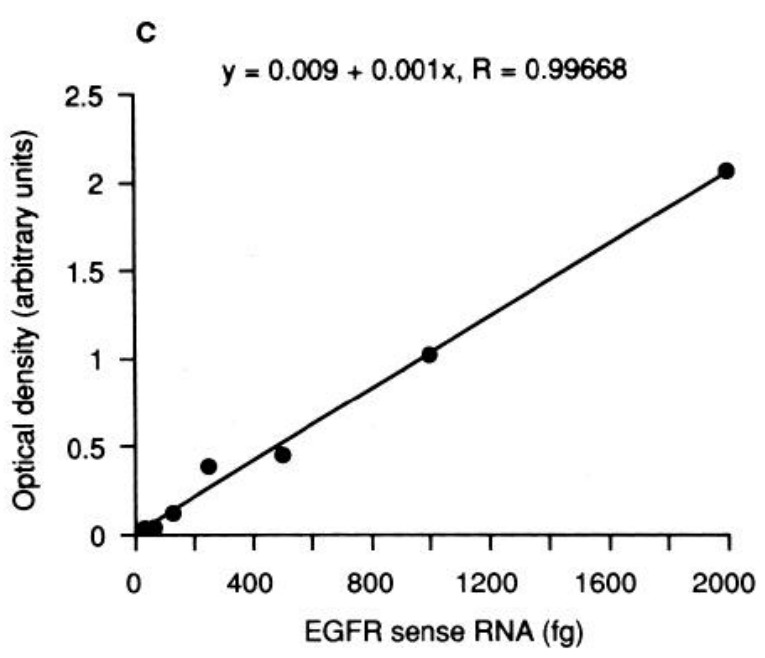

domain of the full-length EGFR mRNA and its truncated form, and $223 \mathrm{nt}$ corresponding to the unique $3^{\prime}$ end of the truncated EGFR mRNA.

\section{Lesion-induced changes in EGFR $m R N A s$}

An increase in EGFR mRNA was seen in the POA-AHA $6 \mathrm{~d}$ after the lesion (Fig. 2, top). At this time, uterine weight had increased and accumulation of uterine fluid was detected in half of the lesioned rats. These animals were classified as "stimulated," that is, in the EP-LP phases of puberty. EGFR mRNA levels were similarly elevated in the other half of lesioned rats, which were in the $E$ phase at the time of death. Due to the variability in EGFR mRNA levels in intact juvenile (A phase) rats, the increase after the lesion was statistically significant $(p$ $<0.05$ ) only in the lesioned E group. EGFR mRNA content tended to be higher in intact animals undergoing normal puberty than in juvenile rats, but these differences were not statistically significant. Levels of truncated EGFR mRNA were 10-20 times lower than those of the EGFR mRNA proper, and did not appear to change either after the lesion or during the normal time of puberty (Fig. 2, bottom).

\section{Lesion-induced changes in biochemically active EGFR protein}

Ligand-dependent activation of the EGFR intrinsic tyrosine kinase is an essential step in the signal transduction mechanism that mediates EGF and TGF $\alpha$ biological actions (Carpenter, 1987; Yarden and Ullrich, 1988). This enzyme activity can be experimentally stimulated by divalent antibodies, which presumably act by dimerizing EGFR molecules (Carpenter, 1987; Spaargaren et al., 1991). We utilized this phenomenon to determine if the changes in EGFR mRNA content after POAAHA lesions were accompanied by corresponding changes in EGFR tyrosine kinase activity. Figure 3 shows that the lesion results in a twofold increase in hypothalamic EGFR tyrosine kinase activity as determined by the ability of the enzyme to catalyze the autophosphorylation of EGFR. It is noteworthy that the magnitude of this change was remarkably similar to that observed for EGFR mRNA (Fig. 2).

\section{Immunohistochemical localization of EGFR}

As previously shown in the cerebral cortex with a different antiserum (Nieto-Sampedro et al., 1988b), a marked increase in 

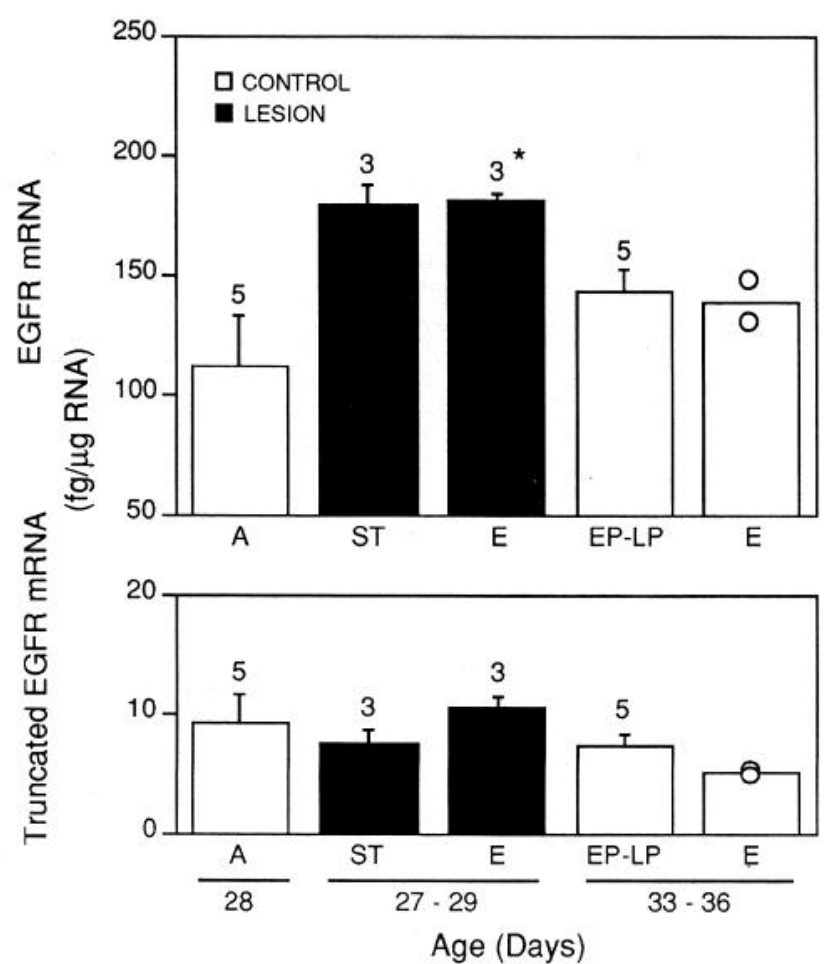

Figure 2. Changes in EGFR mRNA (top) and its truncated form (bottom) after lesioning the POA-AHA of immature female rats. Numbers above bars are number of independent observations per group. Each sample was obtained from a pool of two animals. $A$, juvenile rats, classified as belonging to the A phase of puberty; $S T$, stimulated, that is, animals showing signs of puberty (increased uterine weight and accumulation of intrauterine fluid); EP-LP, animals in the EP and LP phases of normal puberty that precede the first ovulation; $E$, day of first estrus, when ovulation takes place. Vertical bars indicate SEM.

EGFR immunoreactivity was observed in the area surrounding POA-AHA lesions (Fig. 4). The EGFR-like material was detected in both cell bodies and processes directed toward the lesion site (Fig. 4A). Double immunohistochemistry revealed that the EGFR immunoreactivity was confined to reactive as- trocytes (Fig. 4B). Interestingly, not all astrocytes were equally immunoreactive. Instead, the highest levels of EGFR-like material was seen in clusters of astrocytes randomly distributed in the area neighboring the lesion.

\section{Localization of EGFR mRNA by hybridization histochemistry}

Confirming the results obtained with immunohistochemistry, abundant levels of EGFR mRNA were detected in cells surrounding the lesion site, and most predominantly in cell clusters (Fig. 5). Localization of EGFR mRNA-positive cells corresponded closely to the area in which EGFR immunoreactivity was identified. We recently reported (Ma et al., 1991) that EGFR mRNA expression in the POA-AHA in intact rats is modest and limited to cells scattered through the area.

\section{Simultaneous localization of $L H R H$ and EGFR immunoreactivities}

Double immunohistochemistry demonstrated the presence of LHRH perikarya (Fig. $6 A-C$, single arrows; smooth appearance of the staining) in the vicinity of the lesion and in proximity to EGFR-positive cells (arrowheads; crystal-like appearance). While in no instance were LHRH neurons found to be EGFR immunopositive, in several cases they appeared closely associated with EGFR-positive cells. Figure $6 C$ depicts one of such cases; an EGFR-positive cell (arrowhead) can be seen overlying an LHRH neuron devoid of EGFR-immunoreactive material (double arrows). Examination of the ventral aspect of the lesion revealed the presence of LHRH nerve terminals coursing toward the site of the lesion instead of traveling, as in intact animals, toward the median eminence. Although in intimate contact with processes from EGFR-positive cells, the LHRH terminals themselves did not exhibit EGFR immunoreactivity (Fig. 6D).

\section{Discussion}

The results of this study demonstrate that hypothalamic lesions that elicit sexual precocity activate expression of the gene encoding EGFR in reactive astrocytes surrounding the lesion site. The increase in EGFR mRNA was accompanied by corresponding increases in biochemically active EGFR protein and in EGFRimmunoreactive material. The latter is in agreement with an
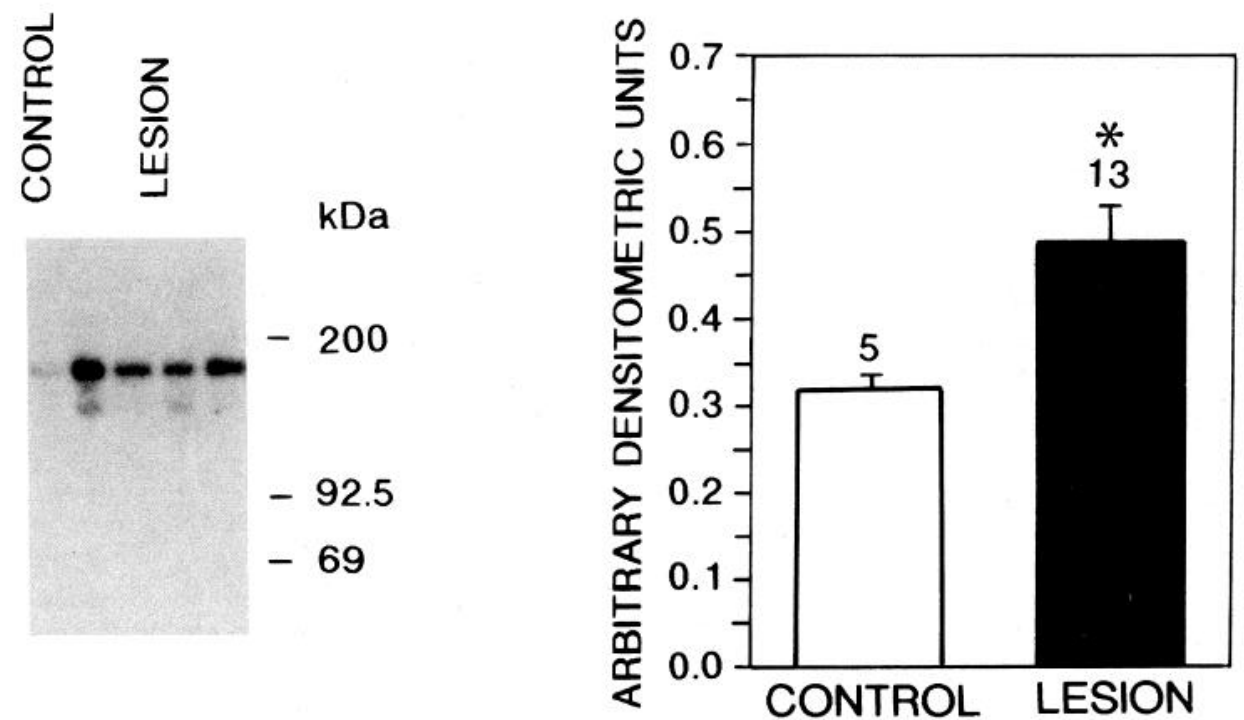

Figure 3. Detection of lesion-induced changes in biochemically active EGFRs by antibody-mediated activation of EGFR tyrosine kinase, followed by SDSPAGE separation of the autophosphorylated receptor species. The left panel shows an autoradiogram depicting the results of one experiment. The right panel presents the results of the densitometric analysis of three different experiments. Numbers above bars are number of independent observations per group. ${ }^{*}, p<0.025$ versus intact control group. Vertical bars indicate SEM. 


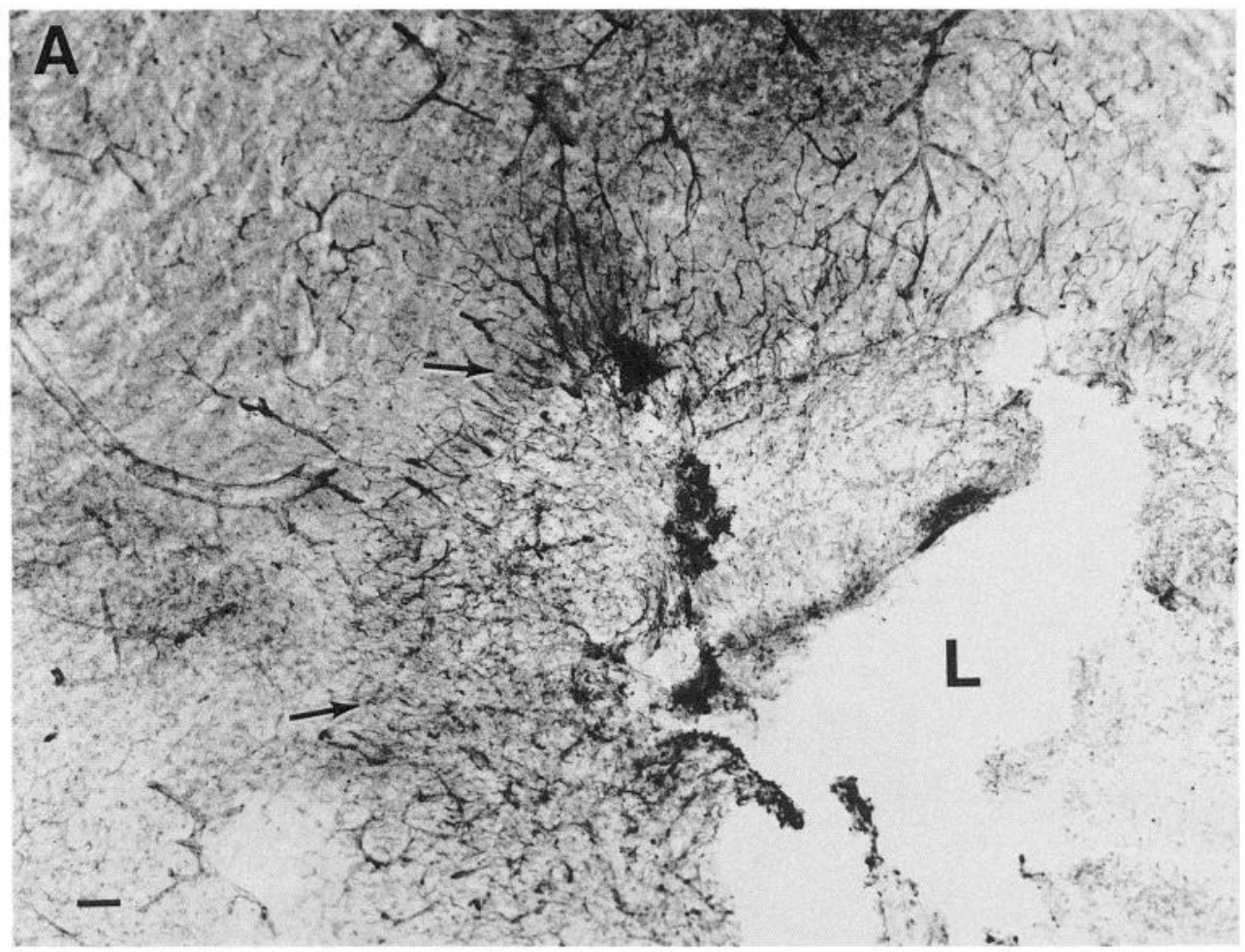

Figure 4. Detection of immunoreactive EGFRs in the area surrounding a POA-AHA lesion. $A$, Low-magnification view of the lesioned area. $L$, lesion. Arrows show immunopositive cells. B, Double immunohistochemistry for EGFRs (arrow, crystal-like reaction) and the astrocyte cytoskeletal protein GFAP (arrowheads, smooth-looking reaction). In the original photograph, EGFR-immunoreactive material has a blue color and GFAP has a brown color. Scale bars: $A, 500 \mu \mathrm{m} ; B, 10 \mu \mathrm{m}$.

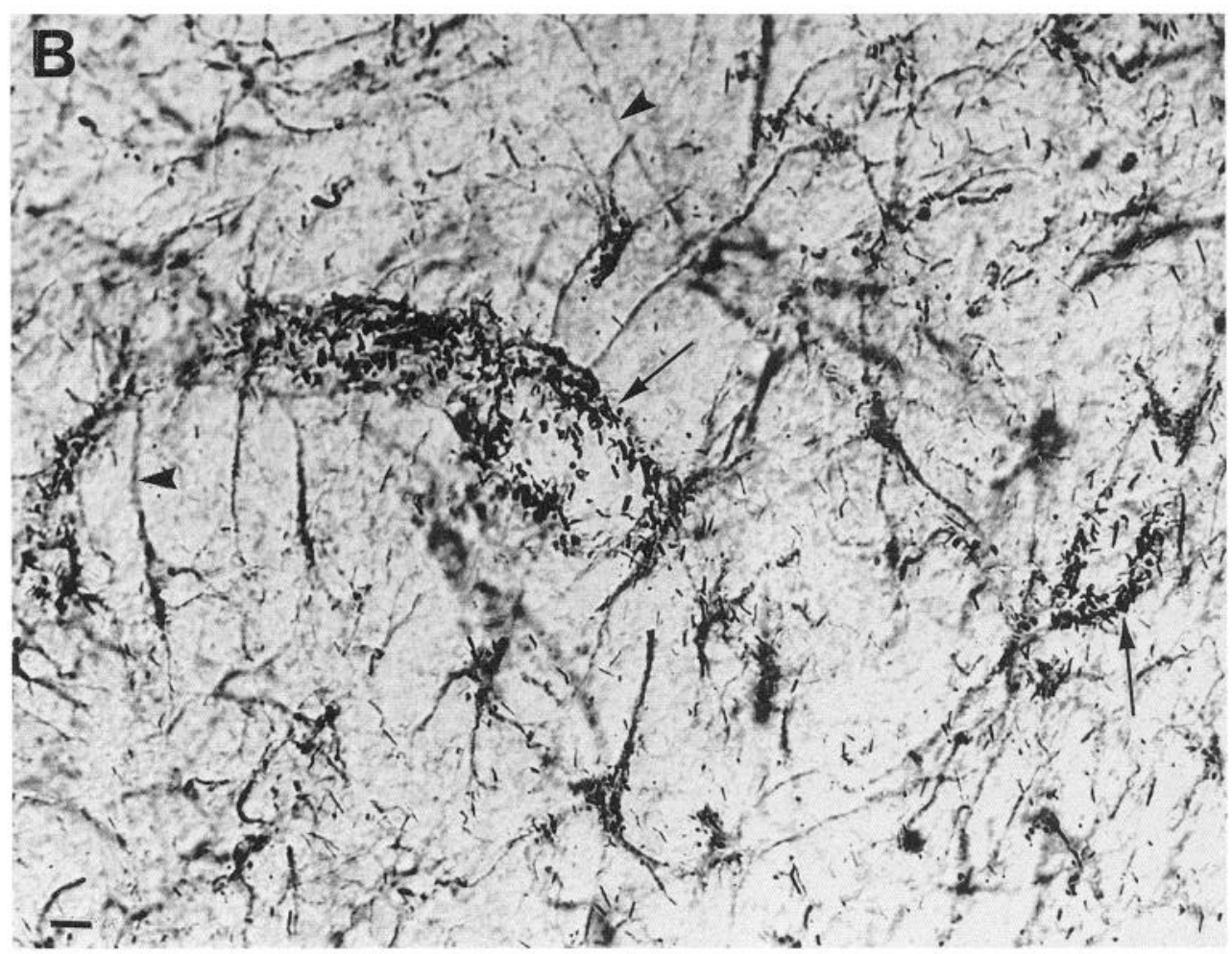

earlier report showing an increase in EGFR immunoreactivity in reactive astrocytes following lesions of the entorhinal cortex of adult rats (Nieto-Sampedro et al., 1988b).

TGF $\alpha$ mRNA levels are also elevated in reactive astrocytes surrounding POA-AHA lesions (Junier et al., 1991b), suggesting that astroglial expression of the TGF $\alpha$ and EGFR genes is coordinately regulated after injury. It would not appear that a similar mechanism regulates EGF synthesis, since no EGF
mRNA was detected by RNA blot hybridization either in the intact hypothalamus or after injury (Ojeda et al., 1990; Junier et al., 1991b). It is possible, however, that EGF mRNA levels do increase after injury, but the sensitivity of blot hybridization is not sufficient to detect the change. While recent attempts to detect EGF mRNA in normal brain have been unsuccessful (Yeh et al., 1990; Kaser et al., 1991), other authors (Lazer et al., 1988; Lazar and Blum, 1992) utilized RNase protection assays to dem- 


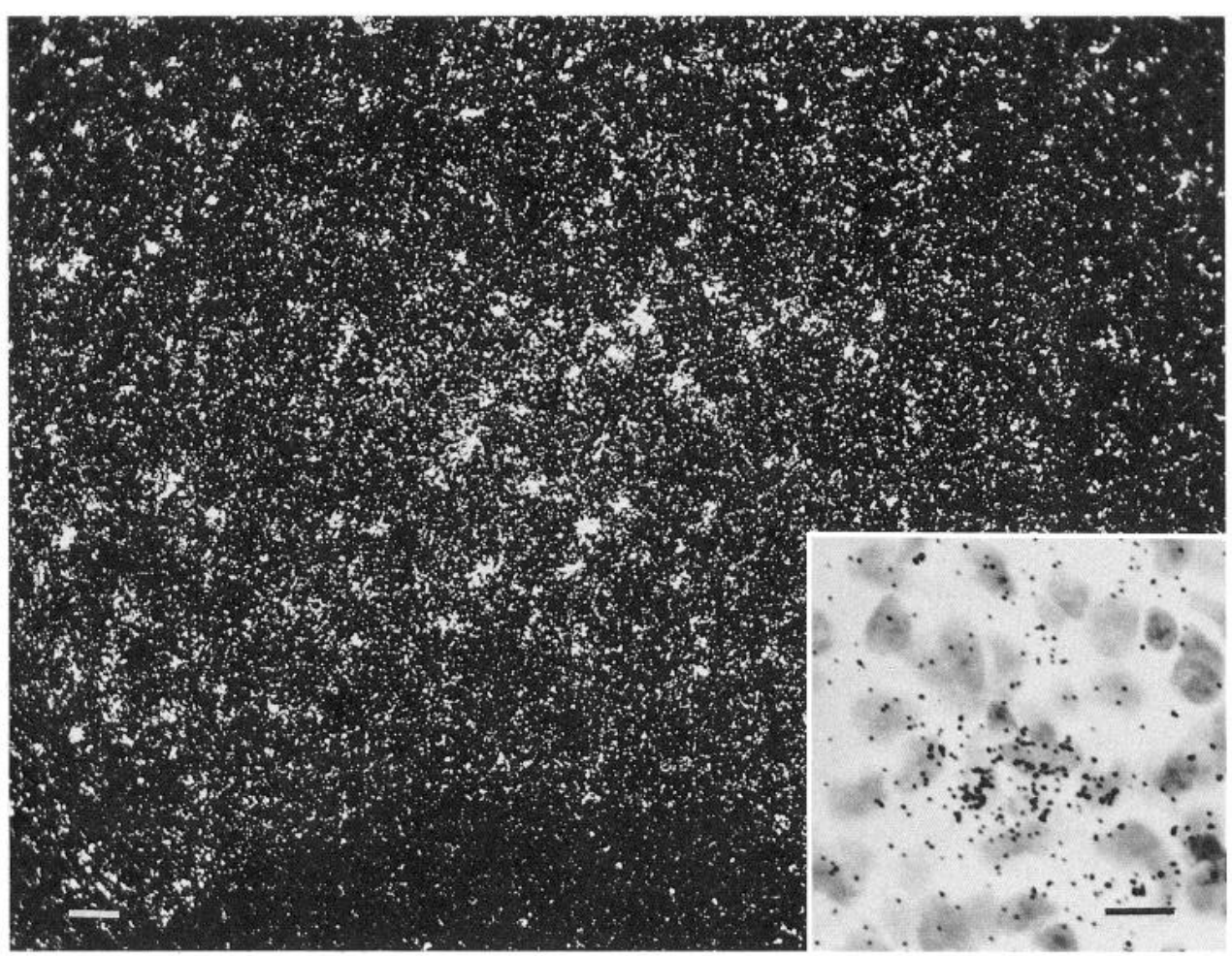

Figure 5. EGFR mRNA detected by hybridization histochemistry in cells surrounding the site of a POA-AHA lesion. Notice the clusters of EGFR mRNA-positive cells and the presence of other more disperse positive cells. Inset, bright-field microphotograph of EGFR mRNA-positive cells. Scale bars: main panel, $100 \mu \mathrm{m}$; inset, $10 \mu \mathrm{m}$. onstrate that EGF mRNA is present in brain at exceedingly low levels (about $1 / 10$ th to $1 / 20$ th of TGF $\alpha$ mRNA). In view of these findings, it is reasonable to assume that TGF $\alpha$ is the preferred physiological ligand for brain EGFR.

It has been shown in normal human keratinocytes (Coffey et al., 1987) that TGF $\alpha$ acts in an autocrine fashion to increase its own production. EGF, as TGF $\alpha$ initiates its biological actions by interacting with EGFRs, has also been shown to increase TGF $\alpha$ mRNA levels in normal human keratinocytes (Pittelkow et al., 1989), normal human breast epithelial cells (Bates et al., 1990), anterior pituitary cells (Mueller et al., 1989), and breast cancer cell lines (Bjorge et al., 1989). The ability of EGF to enhance EGFR synthesis (Bjorge et al., 1989) suggests that this may be a mechanism by which an elevated expression of the two genes is perpetuated in malignant transformation. These findings also raise the possibility that a similar process occurs in astroglial cells after injury, and that once TGF $\alpha$ gene expression is activated in reactive astrocytes, TGF $\alpha$ itself-acting in a paracrine and/or autocrine fashion-contributes to enhancing its own expression and that of EGFR. Recent studies in our laboratory (Ma et al., 1992), which demonstrate the ability of TGF $\alpha$ to increase TGF $\alpha$ mRNA levels in cultures of purified hypothalamic astrocytes, support this view.

The identity of the primary mechanisms responsible for the initial activation of TGF $\alpha$ synthesis in reactive astrocytes has not been elucidated. It is likely, however, that such mechanisms are tightly related to factors released immediately after injury by blood-derived invading macrophages and activated microglia (Nieto-Sampedro and Cotman, 1985; Streit et al., 1990). This view is indirectly supported by several observations, including the very early onset of astrogliosis (defined by an increase in GFAP mRNA) after injury (Condorelli et al., 1990), the release of a variety of astrocytic mitogens such as interleukin-1, aFGF, bFGF, and TGF $\alpha$ itself by activated macrophages and microglia (Giulian and Lachman, 1985; Nieto-Sampedro and Berman,
1987; Finklestein et al., 1988; Giulian et al., 1988; Nieto-Sampedro et al., 1988a; Rappolee et al., 1988), and by the ability of some of these factors to induce astrogliosis (Eclancher et al., 1990).

Interestingly, EGFR mRNA content and EGFR immunoreactivity were greater in reactive astrocytes grouped in clusters than in those more evenly distributed around the lesion. Such a feature was not apparent in the case of TGF $\alpha$ (Junier et al., $1991 \mathrm{~b}$ ), suggesting that close proximity among TGF $\alpha$-producing astrocytes favors the synthesis of EGFR. While a definitive explanation for this phenomenon is not at hand, the ability of TGF $\alpha$ to act in a juxtacrine fashion, that is, by directly binding to adjacent EGFR-bearing cells without being cleaved from its transmembrane precursor (Brachmann et al., 1989; Massagué, 1990), raises the possibility that juxtacrine stimulation underlies some of the effects of glial-derived TGF $\alpha$ on glial cells.

Alternative splicing of the EGFR mRNA primary transcript resulting in a shorter form that encodes most of the extracellular domain of EGFR has been shown to be a normal feature in rat liver (Petch et al., 1990) and to also occur in rat brain (Ma et al., 1991). The product of this truncated mRNA transcript that bears the EGFR binding domain is secreted in large amounts by rat hepatocytes (Petch et al., 1990). In intact brain, however, the truncated EGFR mRNA is produced at exceedingly low levels (less than 1/10th of the full-length species), suggesting that only small amounts of its protein product may be secreted. The present results indicate that the content of truncated EGFR mRNA does not change after POA-AHA lesions, suggesting that activation of the EGFR gene in reactive astrocytes involves differential regulation of the splicing pattern of its mRNA, and that this leads to preferential formation of the full-length EGFR mRNA. The results also suggest that even if small amounts of truncated receptor are secreted within the hypothalamus, they may not change after injury. Such a change, if it occurred, would be difficult to detect because of the exceedingly low levels of 

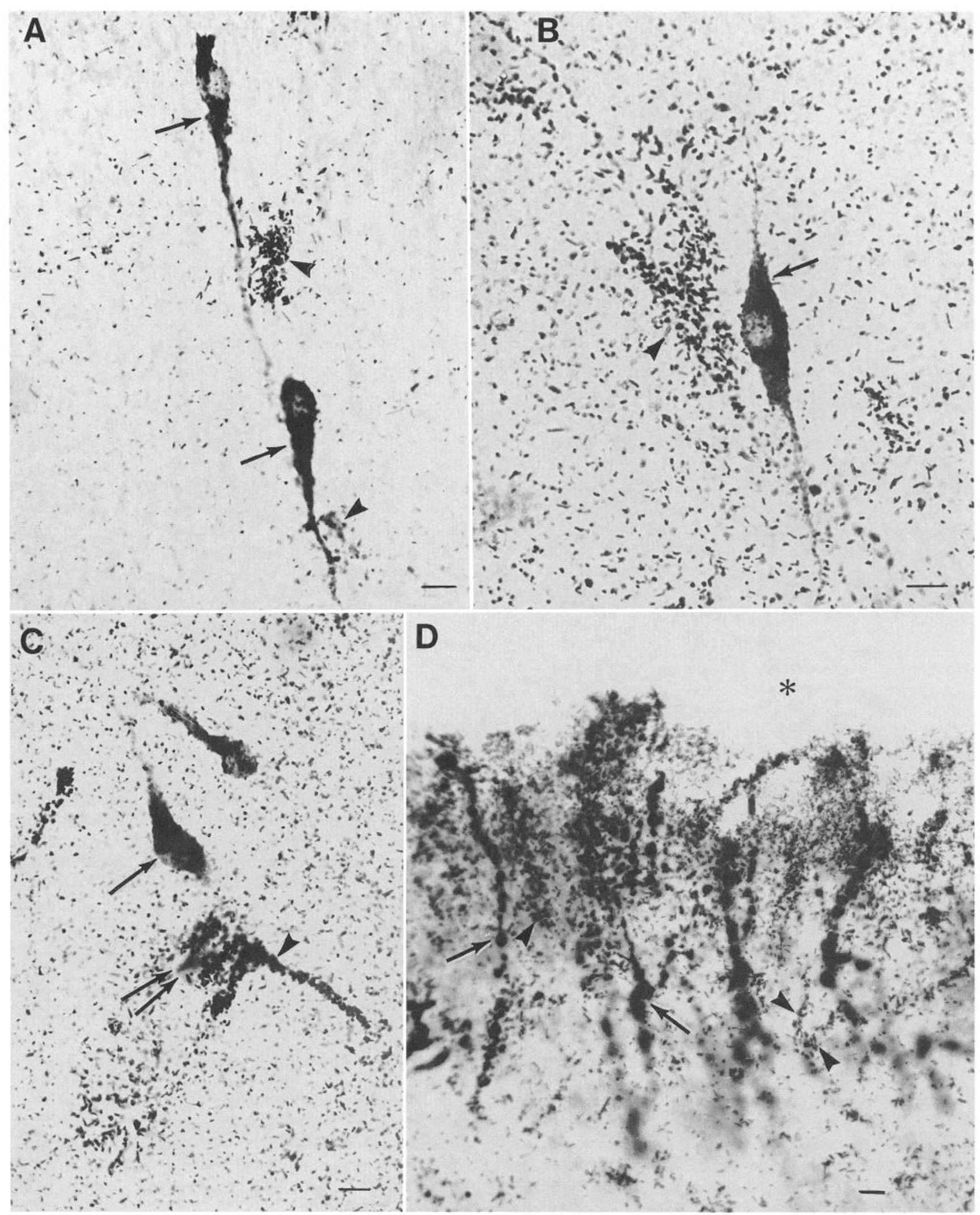

Figure 6. Double immunohistochemistry demonstrating the absence of EGFR immunoreactivity in LHRH neurons. In the original tissue sections, LHRH staining has a brown color and a smooth appearance whereas EGFR immunoreactivity has a blue color and crystal-like appearance. $A-C$, LHRH neurons (single arrows) in close vicinity of EGFR-positive cells (arrowheads). In C, the double arrows point to an LHRH neuron located directly underneath an EGFR-positive cell (arrowhead). D, LHRH nerve terminals (arrows) coursing toward the site of the lesion (asterisk) in the ventral aspect of the anterior hypothalamus. Notice that the LHRH terminals are devoid of EGFR immunoreactivity, which is abundant in closely apposed neighboring cell processes (arrowheads). Scale bars, $10 \mu \mathrm{m}$. 
truncated EGF mRNA levels found in both intact and lesioned rats. The selective increase in EGFR gene expression after lesion suggests that an increased availability of EGFRs for ligand interaction in the face of low expression of the truncated EGFR form may be important for the amplification of the TGF $\alpha$ stimulatory signal to occur.

A recent report described the presence of a secreted astrocyte mitogen inhibitor related to EGFR in rat brain (Nieto-Sampedro, 1988). Lower levels of the inhibitor were found in injured than in intact brain; since binding of the inhibitor to EGFR antibodies resulted in increased EGFR immunoreactivity in astrocytes in both in vivo and in vitro experiments, it was postulated that a decreased production of the inhibitor after injury contributes to the appearance of reactive astrocytes and their proliferation. The present observations raise the possibility that the astrocyte mitogen inhibitor described by Nieto-Sampedro (1988) may be the product of the truncated form of EGFR mRNA. Although the apparent absence of changes in truncated EGFR mRNA after POA-AHA lesions makes this less likely, it should be recognized that not always does the steady state level of EGFR mRNA reflect the amount of EGFR protein synthesized. A prominent example of this is the human epidermoid carcinoma cell line A-431, which contains 50-100 times more EGFR protein than any other EGFR-bearing cell, and yet it expresses normal levels of EGFR mRNA (Ullrich et al., 1984). On the other hand, the recombinant soluble extracellular domain of the human EGFR expressed in Chinese hamster ovary (CHO) cells or in the baculovirus system has been shown to have an affinity for EGF two orders of magnitude lower than the membrane-bound EGFR (Hurwitz et al., 1991). Thus, if the rat soluble EGFR behaved similarly, it would have to be expressed at very high levels to be able to exert meaningful physiological effects. The availability of antibodies specific to the truncated rat EGFR should allow one to determine if this protein is indeed secreted by astrocytes.

TGF $\alpha$ is thought to mediate the advancing effect of POAAHA lesions on sexual development via its stimulatory effect on LHRH secretion (Junier et al., 1991b, 1992). This effect has been postulated to require the intermediacy of glial cells, which upon TGF $\alpha$ stimulation produce prostaglandins that act on LHRH nerve terminals to enhance LHRH release. Initial support of this concept is provided by observation that blockade of prostaglandin synthesis prevents the effect of TGF $\alpha$ on LHRH release (Ojeda et al., 1990) and by the recent finding that POAAHA lesions enhance I.HRH release without affecting L.HRH gene expression (Junier et al., 1992). An additional piece of evidence required to substantiate this hypothesis further is the demonstration that EGFRs are located on reactive astrocytes rather than on LHRH neurons. The present results provide such evidence and further demonstrate that, as suspected (Junier et al., 1991b), EGFR-positive glia in the lesioned POA-AHA are in close proximity to both LHRH nerve terminals and LHRH neuronal perikarya. In no instance were LHRH neurons found to be EGFR positive, in spite of the marked increase in EGFR immunoreactivity detected in neighboring glial cells. LHRH neurons in intact juvenile animals are also EGFR negative (Ma et al., 1991), indicating that they do not express the receptor during this phase of postnatal development. It must be pointed out, however, that low levels of EGFR rcceptors may be present in a subset of LHRH neurons and/or during embryonic development and escaped detection because of the sensitivity of the immunohistochemical procedure used.
The simultaneous increase in EGFR and TGF $\alpha$ in reactive astrocytes may provide the necessary amplification for TGF $\alpha$ to exert its stimulatory effects on LHRH secretion and cause scxual prccocity. It is unknown whether a similar intcraction occurs in human cases of idiopathic precocious puberty of central origin, but our results and the recent demonstration that the vast majority of human CNS tumors of glial origin contain functional EGFRs (Baugnet-Mahieu et al., 1990) suggest that this may be the case.

\section{References}

Advis JP, Ramirez VD (1977) Plasma levels of LH and FSH in female rats with precocious puberty induced by hypothalamic lesions. Biol Reprod 17:313-320.

Advis JP, Andrews WW, Ojeda SR (1979) Changes in ovarian steroidal and prostaglandin $E$ responsiveness to gonadotropins during the onset of puberty in the female rat. Endocrinology 104:653-658.

Bakhit C, Armanini M, Bennett GL, Wong WLT, Hansen SE, Taylor $R$ (1991) Increase in glial-derived growth factor following destruction of hippocampal neurons. Brain Res 560:76-83.

Balagura S, Shulman K, Sobel EH (1979) Precocious puberty of cerebral origin. Surg Neurol 11:315-326.

Bates SE, Valverius EM, Ennis BW, Bronzert DA, Sheridan JP, Stampfer MR, Mendelsohn J, Lippman ME, Dickson RB (1990) Expression of the transforming growth factor- $\alpha$ /epidermal growth factor receptor pathway in normal human breast epithelial cells. Endocrinology 126: 596-607.

Baugnet-Mahieu L, Lemaire M, Brotchi J, Levivier M, Born J, Gilles J, Valkenaers-Michaux A, Vanghell V (1990) Epidermal growth factor receptors in human tumors of the central nervous system. Anticancer Res 10:1275-1280.

Bjorge JD, Paterson AJ, Kudlow JE (1989) Phorbol ester or epidermal growth factor (EGF) stimulates the concurrent accumulation of mRNA for the EGF receptor and its ligand transforming growth factor- $\alpha$ in a breast cancer cell line. J Biol Chem 264:4021-4027.

Brachmann R, Lindquist PB, Nagashima M, Kohr W, Lipari T, Napier M, Derynck R (1989) Transmembrane TGF- $\alpha$ precursors activate EGF/TGF- $\alpha$ receptors. Cell 56:691-700.

Cacciari E, Frejaville E, Cicognani A, Pirazzoli P, Frank G, Balasmo A, Tassinari D, Zappula F, Bergamaschi R, Cristi GF (1983) How many cases of true precocious puberty in girls are idiopathic? J Pediatr 102:357-360.

Carpenter G (1987) Receptors for epidermal growth factor and other polypeptide mitogens. Annu Rev Biochem 56:881-914.

Chomczynski P, Sacchi N (1987) Single-step method of RNA isolation by acid guanidinium thiocyanate-phenol-chloroform extraction. Anal Biochem 162:156-159.

Coffey RJ Jr, Derynck R, Wilcox JN, Bringman TS, Goustin AS, Moses HL, Pittelkow MR (1987) Production and auto-induction of transforming growth factor- $\alpha$ in human keratinocytes. Nature 328:817820 .

Condorelli DF, Dell'Albani P, Kaczmarek L, Messina L, Spampinato G, Avola R, Messina A, Giuffrida Stella AM (1990) Glial fibrillary acidic protein messenger RNA and glutamine synthetase activity after nervous system injury. J Neurosci Res 26:251-257.

Critchlow VC, Bar-Sela ME (1967) Control of the onset of puberty. In: Neuroendocrinology, Vol 2 (Martini L, Ganong WF, cds), pp 101162. New York: Academic.

Danielsson PE, Forss-Peter S, Brow MA, Calavetta L, Milner RJ, Sutcliffe JG (1988) p1B15: a cDNA clone of the rat mRNA encoding cyclophilin. DNA 7:261-267.

Decker SJ (1984) Aspects of the metabolism of the epidermal growth factor receptor in A431 human epidermoid carcinoma cells. Mol Cell Biol 4:571-575.

DeGroot J (1959) The rat hypothalamus in stereotaxic coordinates. J Comp Neurol 113:389-400.

Dissen GA, Hill DF, Costa ME, Ma YJ, Ojeda SR (1991) Nerve growth factor receptors in the peripubertal rat ovary. Mol Endocrinol 5:16421650 .

Donovan BT, van der Werff Ten Bosch JJ (1956) Precocious puberty in rats with hypothalamic lesions. Nature 178:745.

Eclancher F, Perraud F, Faltin J, Labourdette G, Sensenbrenner M 
(1990) Reactive astrogliosis after basic fibroblast growth factor (bFGF) injection in injured neonatal rat brain. Glia 3:502-509.

Finklestein SP, Apostolides PJ, Caday CG, Prosser J, Philips MF, Klagsbrun $M$ (1988) Increased basic fibroblast growth factor (bFGF) immunoreactivity at the site of focal brain wounds. Brain Res 460:253259.

Gilman M (1989) Ribonuclease protection assay. In: Current protocols in molecular biology, Vol 1 (Ausubel FM, Brent R, Kingston RE, Moore DD, Seidman JG, Smith JA, Struhl K, eds), pp 4.7.1-4.7.6. New York: Green and Wiley-Interscience.

Giulian D, Lachman LB (1985) Interleukin-1 stimulation of astroglial proliferation after brain injury. Science 228:497-499.

Giulian D, Young DG, Woodward J, Brown DC, Lachman LB (1988) Interleukin-1 is an astroglial growth factor in the developing brain. J Neurosci 8:709-714.

Hill DF, Dissen GA, Ma YJ, Ojeda SR (1992) Detection of nerve growth factor and one of its receptors. In: Methods in neurosciences, Vol 9, Gene expression in neural tissue (Conn PM, ed,) pp 179-196. New York: Academic.

Hurwitz DH, Emanuel SL, Nathan MH, Sarver N, Ullrich A, Felder S, Lax I, Schlessinger J (1991) EGF induces increased ligand binding affinity and dimerization of soluble epidermal growth factor (EGF) receptor extracellular domain. J Biol Chem 266:22035-22043.

Junier M-P, Hill DF, Costa ME, Ojeda SR (1991a) Hypothalamic lesions that induce female precocious puberty activate glial expression of the epidermal growth factor receptor gene: differential regulation of alternatively spliced transcripts. Soc Neurosci Abstr 17:906.

Junier M-P, Ma YJ, Costa ME, Hoffman G, Hill DF, Ojeda SR (1991b) Transforming growth factor alpha contributes to the mechanism by which hypothalamic injury induces precocious puberty. Proc Natl Acad Sci USA 88:9743-9747.

Junier M-P, Wolff A, Hoffman GE, Ma YJ, Ojeda SR (1992) Effect of hypothalamic lesions that induce precocious puberty on the morphological and functional maturation of the luteinizing hormonereleasing hormone system. Endocrinology 131:787-798.

Kaplan SL, Grumbach MM (1990) Pathogenesis of sexual precocity. In: Control of the onset of puberty (Grumbach MM, Sizonenko PC, Aubert ML, eds), pp 620-668. Baltimore: Williams and Wilkins.

Kaser M, Lakshmanan J, Huff K, Fisher DA (1991) Rat brain contains messenger RNAs for EGF-receptor and TGF-alpha but not for EGF. Soc Neurosci Abstr 17:223.

Klempt ND, Williams C, Sirimanne E, Gluckman PD (1991) Transforming growth factor beta expression in the rat brain is markedly increased after a hypoxic-ischemic insult. Prog 73rd Annu Mtg Endocrine Soc 483

Kris RM, Lax I, Gullick W, Waterfield MD, Ullrich A, Fridkin M, Schlessinger J (1985) Antibodies against a synthetic peptide as a probe for the kinase activity of the avian EGF receptor and v-erbB protein. Cell 40:619-625.

Lakos S, Basbaum AI (1986) Benzidine dihydrochloride as a chromogen for single- and double-label light and electron microscopic immunocytochemical studies. J Histochem Cytochem 34:1047-1056.

Lara HE, Hill DF, Katz KH, Ojeda SR (1990) The gene encoding nerve growth factor is expressed in the mature rat ovary: effect of denervation and hormonal treatment. Endocrinology 126:357-363.

Lazar LM, Blum M (1992) Regional distribution and developmental expression of epidermal growth factor and transforming growth factor- $\alpha$ mRNA in mouse brain by a quantitative nuclease protection assay. J Neurosci 12:1688-1697.

Lazar LM, Roberts JL, Blum M (1988) Regional distribution of epidermal growth factor mRNA in the mammalian central nervous system. Soc Neurosci Abstr 14:1162.

Leutz A, Schachner M (1981) Epidermal growth factor stimulates DNA synthesis of astrocytes for primary cerebellar cultures. Cell Tissue Res 220:393-404.

Logan A, Hill DJ, Gonzalez A-M, Frautschy SA, Baird A (1991) Focal increase of peptide growth factors in the injured rat brain. Prog 73rd Annu Mtg Endocrine Soc 482.

Ma YJ, Junier M-P, Hill DF, Felder S, Ojeda SR (1991) Expression of the transforming growth factor alpha (TGF $\alpha$ )-epidermal growth factor (EGF) receptor system in the developing female hypothalamus: changes during the onset of puberty. Prog 73rd Annu Mtg Endocrine Soc 303.

Ma YJ, Moholt-Siebert M, Hill DF, Ojeda SR (1992) Regulation of transforming growth factor alpha (TGF $\alpha$ ) mRNA expression in rat hypothalamic astrocytes by TGF $\alpha$ and estradiol $\left(E_{2}\right)$. Soc Neurosci Abstr 18:1449.

Marks SR, Elders JM (1979) The child with precocious puberty. J Natl Med Assoc 71:153-159.

Massagué J (1990) Transforming growth factor- $\alpha$. J Biol Chem 265: 21393-21396.

Mueller SG, Kobrin MS, Paterson AJ, Kudlow JE (1989) Transforming growth factor- $\alpha$ expression in the anterior pituitary gland: regulation by epidermal growth factor and phorbol ester in dispersed cells. Mol Endocrinol 3:976-983.

Nieto-Sampedro M (1988) Astrocyte mitogen inhibitor related to epidermal growth factor receptor. Science 240:1784-1786.

Nicto-Sampedro M, Berman MA (1987) Interleukin-1-like activity in rat brain: sources, targets, and effect of injury. J Neurosci Res 17: 214-219.

Nieto-Sampedro M, Cotman CW (1985) Growth factor induction and temporal order in central nervous system repair. In: Synaptic plasticity (Cotman CW, ed), pp 407-455. New York: Guilford.

Nieto-Sampedro M, Lim R, Hicklin DJ, Cotman CW (1988a) Early release of glia maturation factor and acidic fibroblast growth factor after rat brain injury. Neurosci Lett 86:361-365.

Nieto-Sampedro M, Gomez-Pinilla F, Knauer DJ, Broderick JT (1988b) Epidermal growth factor receptor immunoreactivity in rat brain astrocytes. Response to injury. Neurosci Lett 91:276-282.

Nilaver G, Kozlomski GP (1989) Comparison of the PAP and ABC immunocytochemical techniques. In: Immunocytochemistry, vol 4 (Bullock GR, Petrusz P, eds), pp 199-215. New York: Academic.

Norman RL, Spies HG (1981) Brain lesions in infant female rhesus monkeys: effects on menarche and first ovulation and on diurnal rhythms of prolactin and cortisol. Endocrinology 108:1723-1729.

Ojeda SR, Urbanski HF (1988) Puberty in the rat. In: The physiology of reproduction (Knobil E, Neill JD, eds), pp 1699-1737. New York: Raven.

Ojeda SR, Urbanski HF, Costa ME, Hill DF, Moholt-Siebert M (1990) Involvement of transforming growth factor alpha in the release of luteinizing-hormone releasing hormone from the developing female hypothalamus. Proc Natl Acad Sci USA 87:9698-9702.

Petch LA, Harris J, Raymond VW, Blasband A, Lee DC, Earp HS (1990) A truncated, secreted form of the epidermal growth factor receptor is encoded by an alternatively spliced transcript in normal rat tissue. Mol Cell Biol 10:2973-2982.

Pittelkow MR, Lindquist PB, Abraham RT, Graves-Deal R, Derynck $\mathrm{R}$, Coffey RJ Jr (1989) Induction of transforming growth factor- $\alpha$ expression in human keratinocytes by phorbol esters. J Biol Chem 264:5164-5171.

Rappolee DA, Mark D, Banda MJ, Werb Z (1988) Wound macrophages express TGF- $\alpha$ and other growth factors in vivo: analysis by mRNA phenotyping. Science 241:708-712.

Silverman A-J (1988) The gonadotropin-releasing hormone (GnRH) neuronal systems: immunocytochemistry. In: The physiology of reproduction, Vol 1 (Knobil E, Neill JD, eds), pp 1283-1304. New York: Raven.

Simmons DM, Arriza JL, Swanson LW (1989) A complete protocol for in situ hybridization of messenger RNAs in brain and other tissues with radiolabeled single-stranded RNA probes. J Histochem 12:169181.

Simpson DL, Morrison R, de Vellis J, Herschman HR (1982) Epidermal growth factor binding and mitogenic activity on purified populations of cells from the central nervous system. J Neurosci Res 8:453-462.

Spaargaren M, Defize LHK, Boonstra J, de Laat SW (1991) Antibodyinduced dimerization activates the epidermal growth factor receptor tyrosine kinase. I Biol Chem 266:1733-1739.

Streit WJ, Graeber MB, Kreutzberg GW (1988) Functional plasticity of microglia: a review. Glia 1:301-307.

Suarez-Quian CA, Dai M, Onoda M, Kriss RM, Dym M (1989) Epidermal growth factor receptor localization in the rat and monkey testes. Biol Reprod 41:921-932.

Takamiya Y, Kohsaka S, Toya S, Otani M, Mikoshiba K, Tsukada Y (1986) Possible association of platelet-derived growth factor (PDGF) with the appearance of reactive astrocytes following brain injury in situ. Brain Res 383:305-309.

Terasawa E, Noonan JJ, Nass TE, Loose MD (1984) Posterior hypothalamic lesions advance the onset of puberty in the female rhesus monkey. Endocrinology 115:2241-2250. 
Ullrich A, Coussens L, Hayflick JS, Dull TJ, Gray A, Tam AW, Lee J, Yarden Y, Libermann TA, Schlessinger J, Downward J, Mayes ELV, Whittle N, Waterfield MD, Seeburg PH (1984) Human epidermal growth factor receptor cDNA sequence and aberrant expression of the amplified gene in A431 epidermoid carcinoma cells. Nature 309: $418-425$.

Urbanski HF (1991) Monoclonal antibodies to luteinizing hormonereleasing hormone: production, characterization, and immunocytochemical application. Biol Reprod 44:681-686.

Wang S-L, Shiverick KT, Ogilvie S, Dunn W Characterization of epidermal growth factor receptors in astrocytic glial and neuronal cells in primary culture. Endocrinology 124:240247 .
Whittemore SR, Larkfors L, Ebendal T, Holets VR, Ericsson A, Persson $H$ (1987) Increased $\beta$-nerve growth factor messenger RNA and protein levels in neonatal rat hippocampus following specific cholinergic lesions. J Neurosci 7:244-251.

Yaish P, Gazit A, Gilon C, Levitzki A (1988) Blocking of EGF-dependent cell proliferation by EGF receptor kinase inhibitors. Science 242:933-935.

Yarden Y, Ullrich A (1988) Growth factor receptor tyrosine kinases. Annu Rev Biochem 57:443-478.

Yeh J, Rosen K, Villa-Komaroff L (1990) Presence of transforming growth factor-alpha (TGF- $\alpha$ ) mRNA and absence of epidermal growth factor (EGF) $m R N A$ in developing fetal and neonatal mouse brain. Prog 72nd Annu Mtg Endocrine Soc 180. 